\title{
LEGALITAS PEMUNGUTAN PARKIR DI KANTOR-KANTOR PEMERINTAHAN KOTA SEMARANG
}

\author{
Muchamad Arif Agung Nugroho \\ Fakultas Hukum Universitas Wahid Hasyim \\ agungprogresif@gmail.com
}

\begin{abstract}
Abstrak
Praktik pemungutan parkir di kantor-kantor pemerintahan sudah sering kali dialami oleh masyarakat, sehingga menyebabkan masyarakat bertanya-tanya dan menaruh curiga, apakah praktik pemungutan parkir tersebut legal? Berawal dari pertanyaan inilah menyebabkan legalitas pemungutan parkir di kantor-kantor pemerintahan layak dikaji lebih dalam. Tulisan ini menggunakan metode penelitian hukum normatif. Metode ini dipakai karena dalam tulisan ini menguraikan peraturan-peraturan tentang atau yang berkaitan dengan perpakiran, lalu diolah yang nantinya akan ditemukan apakah praktik pemungutan parkir di kantor-kantor pemerintahan memiliki dasar hukum atau tidak? Kalau tidak, apa saja ancaman hukumnya? Maka disimpulkan, bahwa ada 2 jenis pungutan parkir yaitu Pajak Parkir dan Retribusi Parkir. Berdasarkan Pasal 62 ayat (2) UU PDRD dan Pasal 3 ayat (2) Perda 10/2011 PP, tempat parkir yang ada di lingkungan atau disediakan oleh kantor pemerintahan bukanlah objek pajak. Artinya pemarkir kendaraan di kantor-kantor pemerintahan tidak dikenakan biaya alias gratis.

Apabila ada pemungutan parkir di kantor-kantor pemerintahan, maka semua itu adalah ilegal dan pemungutnya terancam sanksi tindak pidana pemerasan sebagaimana tercantum dalam Pasal 368 ayat (1) KUHP.
\end{abstract}

Kata kunci: parkir, pajak parkir, retribusi parkir, keuangan daerah.

\section{A. Pendahuluan}

Seringkali masyarakat dipungut parkir ketika memarkir motor di dalam kantor-kantor pemerintahan. ${ }^{14}$ Hal ini memancing pertanyaan yang mengganjal di benak masyarakat, bukankah pemerintah sebagai pelayan publik sudah seharusnya menyediakan tempat parkir yang gratis?

Dari penelusuran di internet, ditemukan keluhan dari masyarakat tentang praktik pemungutan parkir di kantor-kantor pemerintahan. Sebagaimana yang dikeluhkan Risanda Alirastra Budiantoro ${ }^{15}$, di dalam

\footnotetext{
${ }^{14}$ K. Wibowo, 2015, Hukum Lalu Lintas dan Jalan, Jakarta: Press, Hal 44.

${ }^{15}$ http://abe-21.blogspot.com/2013/08/komersialisasi-lahan-parkir-berpotensi.html
} 
blognya, ia mencurigai bahwa praktik pemungutan parkir di luar badan jalan berpotensi pungli (pungutan liar). Begitu juga dengan Adi ${ }^{16}$ yang mengaku heran, kenapa parkir di kantor pemerintahan ada pemungutan parkir. Ia pun juga mempersoalkan kemana uang parkir itu mengalir.

Ternyata selama ini pernah terjadi praktik pemungutan parkir di kantor pemerintahan yang ditertibkan oleh salah satu pemerintah kota di Indonesia, yaitu penertiban praktik pemungutan parkir di Pengadilan Negeri Pekanbaru yang ditertibkan oleh Dinas Perhubungan, Komunikasi dan Informasi (Dishubkominfo) Kota Pekanbaru. ${ }^{17}$

Praktik pemungutan parkir di kantor-kantor pemerintahan sudah sering kali dialami oleh masyarakat, sehingga menyebabkan masyarakat bertanya-tanya dan menaruh curiga, apakah praktik pemungutan parkir tersebut legal? Berawal dari pertanyaan inilah menyebabkan legalitas pemungutan parkir di kantor-kantor pemerintahan layak dikaji lebih dalam. Apalagi terdapat kejanggalan-kejanggalan dalam praktik tersebut, seperti bagaimana mungkin masyarakat diwajibkan membayar parkir di kantor pemerintahan yang merupakan institusi layanan publik. ${ }^{18}$

Tulisan ini menggunakan metode penelitian hukum normatif. Metode ini dipakai karena dalam tulisan ini menguraikan peraturan-peraturan tentang atau yang berkaitan dengan perpakiran. Peraturan-peraturan tersebut diurutkan berdasar hierarkinya dan ditafsirkan, lalu dikaitkan satu sama lainnya. Dari pengolahan tersebut, nantinya akan ditemukan apakah praktik pemungutan parkir di kantor-kantor pemerintahan memiliki dasar hukum atau tidak? Kalau tidak, apa saja ancaman hukumnya?

Pendekatan yang digunakan dalam penelitian ini adalah dreskriptif. Artinya, tulisan ini menjabarkan apa yang seharusnya berdasarkan peraturan pemerintahan

16 http://pekanbaru.tribunnews.com/2014/06/25/adi-heran-ada-pungutan-parkir-di-kantorpekanbaru/

${ }^{17} \mathrm{http}: / /$ www.pekanbaru.go.id/berita/berita-pemko/679-dishub-tertibkan-parkir-di-pn-

${ }^{18}$ David M. L. Tobing, 2017, Parkir dan Perlindungan Hukum Konsumen, Jakarta: P Press, Hal 25. 
perundang-undangan dan lalu memberi petunjuk-petunjuk berdasarkan peraturan perundang-undangan. Kalau memang praktik pemungutan parkir di kantor-kantor pemerintahan itu ilegal, maka sudah seharusnya dihapus.

Objek kajian ini dibatasi hanya pada Kota Semarang, karena banyak sekali peraturan-peraturan daerah yang mengatur tentang parkir, sehingga objek kajiannya diperkecil hanya sebatas lingkup Kota Semarang agar terarah dan terjangkau. Pemilihan Kota Semarang juga bertujuan supaya tulisan ini bermanfaat sebagai bentuk pengabdian perguruan tinggi Universitas Wahid Hasyim (Unwahas) kepada masyarakat di Kota Semarang, karena kampus tersebut terletak di Kota Semarang.

\section{B. Pembahasan}

Undang-undang Republik Indonesia Nomor 28 Tahun 2009 Tentang Pajak Daerah dan Retribusi Daerah (UU 28/2009 PDRD) ${ }^{19}$ merupakan peraturan perundang-undangan yang memayungi peraturan-peraturan daerah di seluruh Indonesia yang mengatur tentang pemungutan parkir.

Menurut Pasal 2 ayat (2) huruf g UU 28/2009 PDRD, salah satu bentuk Pajak Daerah adalah Pajak Parkir, sebagai berikut bunyinya

\section{Pasal 2}

(1)

(2) Jenis Pajak kabupaten/kota terdiri atas:

a. Pajak Hotel;

b. Pajak Restoran;

c. Pajak Hiburan;

d. Pajak Reklame;

e. Pajak Penerangan Jalan;

f. Pajak Mineral Bukan Logam dan Batuan;

g. Pajak Parkir;

h. Pajak Air Tanah;

i. Pajak Sarang Burung Walet;

j. Pajak Bumi dan Bangunan Perdesaan dan Perkotaan; dan

k. Bea Perolehan Hak atas Tanah dan Bangunan.

${ }^{19}$ Abdul Halim dan Icuk Rangga Bawono, 2017, Pengelolaan Keuangan Negara-Daerah: Hukum, Kerugian Negara, dan Badan Pemeriksa Keuangan, Yogyakarta: UPP STIM YKPN, Hal 31. 
Pengertian Pajak Parkir ${ }^{20}$ diatur dalam Pasal 1 angka 31 UU 28/2009 PDRD, sebagai berikut bunyinya

\section{Pasal 1}

Dalam Undang-undang ini, yang dimaksud dengan:

31. Pajak Parkir adalah pajak atas penyelenggaraan tempat parkir di luar badan jalan, baik yang disediakan berkaitan dengan pokok usaha maupun yang disediakan sebagai suatu usaha, termasuk penyediaan tempat penitipan kendaraan bermotor.

Berdasarkan peraturan tersebut, maka dapat disimpulkan bahwa pajak parkir hanya dikenakan terhadap parkir di luar badan jalan. ${ }^{21}$ Aturan ini diperkuat lagi dengan Pasal 1 angka 5 Peraturan Daerah Kota Semarang Nomor 10 Tahun 2011 Tentang Pajak Parkir (Perda 10/2011 PP) yang berbunyi

\section{Pasal 1}

5. Pajak Parkir adalah pajak atas penyelenggaraan tempat parkir di luar badan jalan, baik yang disediakan berkaitan dengan pokok usaha maupun yang disediakan sebagai suatu usaha, termasuk penyediaan tempat penitipan kendaraan bermotor.

Sedangkan Pasal 1 angka 6 Perda 10/2011 PP berbunyi

\section{Pasal 1}

6. Tempat Parkir adalah tempat yang disediakan untuk menyelenggarakan parkir di luar badan jalan yang disediakan oleh orang pribadi atau badan, baik yang disediakan berkaitan dengan pokok usaha maupun yang disediakan sebagai suatu usaha, termasuk penyediaan tempat penitipan kendaraan bermotor.

Maka, berdasar hukum di atas, yang dimaksud dengan tempat parkir di luar badan jalan adalah tempat yang khusus disediakan untuk parkir oleh orang 56.

${ }^{20}$ Darwin, 2016, Pajak Daerah dan Retribusi Daerah, Jakarta: Mitra Wacana Media, Hal

${ }^{21}$ T. Kreatif, 2009, Pajak Daerah dan Retribusi Daerah, Jakarta: Fokus Media, Hal 13. 
pribadi atau badan. Jadi, ketika ada masyarakat yang memarkir kendaraannya di lahan swasta, katakanlah parkir di area pasar swalayan, maka pungutan parkir yang dibayarkan itu merupakan suatu pajak parkir.

Selain pajak parkir, ada juga bentuk pungutan parkir yang bernama Retribusi Parkir. Menurut Pasal 110 ayat (1) UU 28/2009 PDRD, disebutkan bahwa salah satu jenis Retribusi Jasa Umum adalah Retribusi Pelayanan Parkir di Tepi Jalan Umum atau lazim dikenal dengan sebutan Retribusi Parkir. Menurut Pasal 115 UU 28/2009 PDRD, disebutkan bahwa Retribusi Parkir dikenakan terhadap layanan parkir di tepi jalan umum berdasarkan Peraturan Daerah (Perda). ${ }^{22}$

Di Kota Semarang ${ }^{23}$, Retribusi Parkir diatur di dalam Peraturan Daerah Kota Semarang Nomor 2 Tahun 2012 Tentang Retribusi Jasa Umum (Perda 2/2012 RJU), khususnya di dalam Bab VII Retribusi Pelayanan Parkir di Tepi Jalan Umum. Pasal 33 dan 34 Perda 2/2012 RJU menentukan bahwa objek dan subjek Retribusi Parkir adalah orang atau badan yang menggunakan atau menikmati fasilitas parkir di tepi jalan umum. ${ }^{24}$ Jadi dapat disimpulkan, bahwa Retribusi Parkir hanya dipungut bagi siapa saja yang parkir di tepi jalan umum.

Berdasarkan dasar-dasar hukum di atas, maka dapat disimpulkan bahwa ada dua jenis Pungutan Parkir, yaitu (a) Pajak Parkir dan (b) Retribusi Parkir. Spesifikasi dan perbedaan kedua pungutan tersebut dijabarkan dalam tabel berikut:

\begin{tabular}{|l|l|l|}
\hline & \multicolumn{1}{|c|}{ Pajak Parkir } & \multicolumn{1}{c|}{ Retribusi Parkir } \\
\hline Jenis & Pajak Daerah & Retribusi Daerah: \\
Pungutan & & - Retribusi Jasa Umum \\
& & - Retribusi Jasa Usaha \\
\hline Dasar & Perda 10/2011 Pajak Parkir & - Perda 2/2012 Retribusi Jasa Umum \\
\hline
\end{tabular}

${ }^{22}$ Marihot Pahala Siahaan, 2008, Pajak Daerah dan Retribusi Daerah, Jakarta: Rajawali Press, Hal 22.

${ }^{23}$ Siswanto Sunarno, 2016, Hukum Pemerintahan Daerah, Jakarta: Sinar Grafika, Hal 29.

${ }^{24}$ Adrian Sutedi, 2016, Hukum Keuangan Negara, Jakarta: Sinar Grafika, Hal 41. 


\begin{tabular}{|c|c|c|}
\hline Hukum & & - Perda 3/2012 Retribusi Jasa Usaha \\
\hline Lokasi & $\begin{array}{l}\text { Luar Badan Jalan: } \\
\text { - Berkaitan dengan pokok usaha } \\
\text { - Usaha tempat penitipan }\end{array}$ & $\begin{array}{l}\text { - Tepi Jalan Umum (TJU) } \\
\text { - Tempat Khusus Parkir (TKP) } \\
\text { - Terminal }\end{array}$ \\
\hline $\begin{array}{l}\text { Penyeleng- } \\
\text { gara }\end{array}$ & Orang atau Badan & Pemerintah Daerah (Pemda) \\
\hline $\begin{array}{l}\text { Besar } \\
\text { Pungutan }\end{array}$ & $\begin{array}{l}\text { Tidak Diatur / Bebas / Boleh } \\
\text { Gratis }\end{array}$ & $\begin{array}{l}\text { TJU dan TKP: } \\
\text { - Roda dua } 1.000 \\
\text { - Roda Tiga } 1.500 \\
\text { - Roda Empat } 2.000 \\
\text { - Roda Enam } 4.000 \\
\text { - Roda Lebih dari Enam } 7.000 \\
\text { - Insidentil 2x pungutan biasa } \\
\text { Terminal: } \\
\text { - Bus Besar } 3.000 \\
\text { - Bus Sedang } 2.500 \\
\text { - Bus Kecil } 2.000 \\
\text { - Angkot } 1.500\end{array}$ \\
\hline $\begin{array}{l}\text { Pendapatan } \\
\text { Pemda }\end{array}$ & $25 \%$ x Pungutan & $100 \%$ x Pungutan \\
\hline
\end{tabular}

Setelah dilakukan kajian terhadap peraturan-peraturan yang mengatur tentang perparkiran, maka dapat ditarik kesimpulan bahwa parkir di kantorkantor pemerintahah tidak dipungut sama sekali. Hal ini bisa dilihat di Pasal 62 ayat (2) UU PDRD dan Pasal 3 ayat (2) Perda 10/2011 PP, bahwa tempat parkir yang ada di lingkungan atau disediakan oleh kantor pemerintahan bukanlah objek pajak. $^{25}$ Artinya pemarkir kendaraan di kantor-kantor pemerintahan tidak dikenakan biaya alias gratis. Apabila ada pemungutan parkir di kantor-kantor pemerintahan, maka semua itu adalah ilegal dan pemungutnya terancam sanksi pidana. Berikut bunyi pasalnya:

Pasal 62 ayat (2) UU PDRD

${ }^{25}$ Muhammad Djafar Saidi, 2016, Hukum Keuangan Negara, Teori dan Praktik, Jakarta: Rajawali Press, Hal 31. 


\section{Pasal 62}

(2) Tidak termasuk objek pajak sebagaimana dimaksud pada ayat (1) adalah:

a. penyelenggaraan tempat Parkir oleh Pemerintah dan Pemerintah Daerah;

b. penyelenggaraan tempat Parkir oleh perkantoran yang hanya digunakan untuk karyawannya sendiri;

c. penyelenggaraan tempat Parkir oleh kedutaan, konsulat, dan perwakilan negara asing dengan asas timbal balik; dan

d. penyelenggaraan tempat Parkir lainnya yang diatur dengan Peraturan Daerah.

Pasal 3 ayat (2) Perda 10/2011 PP

\section{Pasal 3}

(2) Dikecualikan dari objek pajak parkir sebagaimana dimaksud pada ayat (1) adalah

a. penyelenggara tempat parkir oleh Pemerintah Pusat, Pemerintah Provinsi dan Pemerintah Daerah;

b. penyelenggara tempat parkir oleh perkantoran yang hanya digunakan untuk karyawannya sendiri; dan

c. Penyelenggara tempat parkir oleh kedutaan, konsulat, dan perwakilan negara asing dengan asas timbal balik.

Ancaman pidana yang dapat dikenakan terhadap pemungut parkir tersebut adalah sebagaimana tercantum dalam Pasal 368 ayat (1) Kitab Undang-undang Hukum Pidana (KUHP) yang berbunyi

Barang siapa dengan maksud untuk menguntungkan diri sendiri atau orang lain secara melawan hukum, memaksa seorang dengan kekerasan atau ancaman kekerasan untuk memberikan barang sesuatu, yang seluruhnya atau sebagian adalah kepunyaan orang itu atau orang lain, atau supaya membuat hutang maupun menghapuskan piutang, diancam karena pemerasan dengan pidana penjara paling lama sembilan bulan.

Dengan demikian, pemungut parkir di kantor-kantor pemerintahan Kota Semarang, baik di tingkat atas sampai di tingkat bawah seperti kantor 
kelurahan dapat dipidanakan dengan ancaman hukuman paling lama 9 bulan berdasarkan Pasal 368 ayat (1) KUHP ${ }^{26}$.

\section{Simpulan}

Ada 2 jenis pungutan parkir yaitu Pajak Parkir dan Retribusi Parkir.

Pajak Parkir yaitu jenis pungutannya termasuk pajak daerah, dasar hukumnya adalah Perda 10/2011 PP, lokasi parkirnya berada di luar badan jalan yaitu berkaitan dengan pokok usaha atau usaha tempat penitipan kendaraan, penyelenggaranya adalah orang atau badan hukum, besar pungutannya tidak diatur, terserah pemilik lahan parkir, atau bahkan gratis, lalu pendapatan pemerintah daerah adalah $25 \%$ dari pungutan.

Retribusi parkir yaitu jenis pungutannya adalah retribusi daerah meliputi retribusi jasa umum atau retribusi jasa usaha, dasar hukumnya adalah Perda 2/2012 RJUmum dan Perda 3/2012 RJUsaha, lokasi parkir di Tepi Jalan Umum (TJU), Tempat Khusus Parkir (TKP) atau terminal, penyelenggara atau pemungutnya adalah pemerintah daerah, besaran pungutannya pada TJU dan TKP sebesar roda $2 \mathrm{Rp}$. 1.000,00, roda $3 \mathrm{Rp}$. 1.500,00, roda 4 Rp. 2.000,00, roda 6 Rp. 4.000,00, roda lebih dari 6 Rp. 7.000,00, isidentil 2x pungutan biasa, sedangkan di terminal bus besar Rp. 3.000,00, bus sedang Rp. 2.500,00, bus kecil Rp. 2.000,00, angkot Rp. $1.500,00$, pendapatan pemerintah daerah adalah $100 \%$ dari pungutan.

Berdasarkan Pasal 62 ayat (2) UU PDRD dan Pasal 3 ayat (2) Perda 10/2011 PP, tempat parkir yang ada di lingkungan atau disediakan oleh kantor pemerintahan bukanlah objek pajak. Artinya pemarkir kendaraan di kantor-kantor pemerintahan tidak dikenakan biaya alias gratis.

Apabila ada pemungutan parkir di kantor-kantor pemerintahan, maka semua itu adalah ilegal dan pemungutnya terancam sanksi tindak pidana pemerasan sebagaimana tercantum dalam Pasal 368 ayat (1) KUHP.

\footnotetext{
${ }^{26}$ Tongat, 2015, Hukum Pidana Materiil, Malang: UMM Press, Hal 78.
} 


\section{DAFTAR PUSTAKA}

Abdul Halim dan Icuk Rangga Bawono, 2017, Pengelolaan Keuangan NegaraDaerah: Hukum, Kerugian Negara, dan Badan Pemeriksa Keuangan, Yogyakarta: UPP STIM YKPN.

Adrian Sutedi, 2016, Hukum Keuangan Negara, Jakarta: Sinar Grafika.

Darwin, 2016, Pajak Daerah dan Retribusi Daerah, Jakarta: Mitra Wacana Media.

David M. L. Tobing, 2017, Parkir dan Perlindungan Hukum Konsumen, Jakarta: P Press.

K. Wibowo, 2015, Hukum Lalu Lintas dan Jalan, Jakarta: Press.

Marihot Pahala Siahaan, 2008, Pajak Daerah dan Retribusi Daerah, Jakarta: Rajawali Press.

Muhammad Djafar Saidi, 2016, Hukum Keuangan Negara, Teori dan Praktik, Jakarta: Rajawali Press.

Siswanto Sunarno, 2016, Hukum Pemerintahan Daerah, Jakarta: Sinar Grafika.

T. Kreatif, 2009, Pajak Daerah dan Retribusi Daerah, Jakarta: Fokus Media.

Tongat, 2015, Hukum Pidana Materiil, Malang: UMM Press.

Kitab Undang-undang Hukum Pidana (KUHP)

Undang-undang Republik Indonesia Nomor 28 Tahun 2009 Tentang Pajak Daerah dan Retribusi Daerah

Peraturan Daerah Kota Semarang Nomor 10 Tahun 2011 Tentang Pajak Parkir

Peraturan Daerah Kota Semarang Nomor 2 Tahun 2012 Tentang Retribusi Jasa Umum 